\title{
A portrait of pediatric leadership: Dr. Benjamin Spock
}

\author{
Richard B. Gunderman ${ }^{1}$
}

Received: 6 May 2019 /Revised: 6 May 2019 / Accepted: 28 May 2019 /Published online: 8 June 2019

(C) Springer-Verlag GmbH Germany, part of Springer Nature 2019

Pediatric radiologists can turn to many sources for leadership guidance: programming and publications at professional meetings and journals, courses offered by hospitals and health systems, and degree programs in business and health administration. Yet one of the best sources of insight is right under our noses - predecessors in the field of pediatrics whose leadership has left an enduring imprint on our profession and patients. When it comes to sheer magnitude, no pediatrician in recent memory left a larger mark or offered more inspiration for leaders than Benjamin Spock.

\section{Spock and his book}

Born the eldest child of a New Haven, CT, attorney in 1903, Spock attended Yale University, where he rowed on the varsity crew team that won the gold medal at the 1924 Paris Olympics [1]. He then entered medical school at Yale, eventually transferring to Columbia University, where he graduated first in his class in 1929. He had married Jane Cheney in 1927, and the couple had two sons. Believing that the pediatricians of the day focused too much on physical development, Spock enrolled in the New York Psychoanalytic Institute while also practicing pediatrics in the city.

In conjunction with a 1944-1946 tour of duty in the U.S. Naval Reserve Corps and with the assistance of his wife, Spock began working on his best known book, The Commonsense Book of Baby and Child Care [2, 3]. First published in 1946, the book became a breakaway bestseller. The timing of the book was perfect, entering the market just at the beginning of the so-called baby boom. In the first 6 months

Richard B. Gunderman

rbgunder@iu.edu

1 Department of Radiology,

Riley Hospital for Children,

Indiana University School of Medicine,

702 North Barnhill Drive, Room 1053,

Indianapolis, IN 46202, USA after publication, it sold more than 500,000 copies. Sales eventually numbered more than 50 million copies, and it was translated into more than 40 languages.

For its day, The Commonsense Book of Baby and Child Care was profoundly counter-cultural. Eighteen years prior to its publication, the prevailing view of parenting was well captured by the behaviorist psychologist John Watson, who advised that babies should be tended to on a strict schedule, with affection doled out only sparingly. In 1928, he wrote: "Never kiss your child. Never hold it in your lap. Never rock its carriage" [4]. The rationale? Doing so would only reward the very behaviors - crying and the like - that parents should be working to extinguish.

Spock's approach could hardly have offered a starker contrast. In the first edition of The Commonsense Book of Baby and Child Care, which sold for 25 cents, he wrote:

Don't be afraid to love your baby. ... Every baby needs to be smiled at, talked to, played with, fondled - gently and lovingly.... You may hear people say that you have to get your baby strictly regulated in his feeding, sleeping, bowel movements, and other habits - but don't believe it. He doesn't have to be sternly trained. ... Be natural and comfortable and enjoy your baby [3].

\section{Leadership lessons}

One of the most important leadership lessons of Spock's career was his conviction that people need to listen to their own hearts. The Commonsense Book of Baby and Child Care began: "Trust yourself. You know more than you think you do." Spock encouraged parents not to take too seriously what the neighbors or experts said, and instead trust in their own common sense. He recognized that human beings had been bearing children for a long time before the advent of pediatrics and parenting advice books. Acknowledging that everyone makes mistakes, he believed that "easy confidence" promotes better parenting than worry. 
As a thought leader, Spock manifested a willingness and even eagerness to contradict conventional wisdom. Prior experts on child rearing had offered a largely one-size-fits-all approach, but Spock stressed the individuality of each child. Good parents sought not to make every child fit into a standard mold, but to adapt to the distinctive needs of each, recognizing that what worked well for one might spell disaster for another. His goal was less to make parents conform to his model than to help them discover within themselves the parents they were meant to be.

Spock also saw a natural connection between pediatrics and political activism. He opposed nuclear arms and the war in Vietnam, writing "What is the use of physicians trying to help parents to bring up children who are healthy and happy, only to have them be killed?" [5]. Like the "father of pathology," Rudolf Virchow, Spock regarded medicine as a social science, and politics as medicine on a larger scale [6]. He saw the roots of disease in economic status, education and living conditions, and he believed that interventions to promote health needed to target such broader aspects of life.

Spock also recognized that leaders must be willing to persevere in the face of opposition and even personal attacks. Alarmed at the rebelliousness of young people in the 1960s, Normal Vincent Peale, a proponent of "positive thinking," believed Spock bore the responsibility — "the price of two generations that followed the Dr. Spock baby plan of instant gratification" [7]. Countering such criticism, Spock pointed out that he had never promoted permissiveness, arguing that conservatives were really just lashing out at him for his opposition to the war.

Perhaps Spock's most important leadership contribution was his insistence that the best thing parents could do for their children was not to condition or discipline them but instead to pay attention to them and to love them. He recognized that childrearing is a long, difficult and undervalued job, and he thought that what parents needed above all was encouragement. Parents, he saw, are not cut from a different cloth from their children, but are human beings too, and every bit as vulnerable as their children; the best strategy is for them to grow, explore and learn right along with their children.

Pediatric radiologists, who are called upon to lead every day, can learn much from Spock's example. We, too, must learn to trust our hearts and recognize that every patient, family member, and colleague is a unique human being. We, too, need to look beyond our scanners and reports to the needs of the communities we serve, advocating for those in need. And we, too, need to stick up for what we believe in - above all, the dignity of every human being, however tiny and helpless, contributing to such advocacy as much as we can for as long as we can.

\section{Compliance with ethical standards}

Conflicts of interest None

\section{References}

1. Pace E (1998) Benjamin Spock, world's pediatrician, dies at 94. The New York Times, New York

2. Spock B, Morgan M (1989) Spock on Spock: a memoir of growing up with the century. Pantheon Books, New York

3. Spock BM (1946) The commonsense book of baby and child care. Duell, Sloan, and Pearce, New York

4. Watson JB (1928) Psychological care of the infant and child. The New York Times, New York

5. Campbell R (2008) United States v. Dr. Benjamin Spock. Houston Chronicle, Houston. https://blog.chron.com/40yearsafter/2008/06/ united-states-v-dr-benjamin-spock/. Accessed 23 May 2019

6. Machenbach JP (2009) Politics is nothing but medicine at a larger scale: reflections on public health's biggest idea. J Epidemiol Community Health 63:181-184

7. LIFE editors (2016) LIFE 100 people who changed the world. Time, New York

Publisher's note Springer Nature remains neutral with regard to jurisdictional claims in published maps and institutional affiliations. 